\title{
SISTEM PENDUKUNG KEPUTUSAN DALAM PENENTUAN SUKU CADANG YANG LARIS PADA KHARISMA MOTOR DENGAN METODA TOPSIS DAN BORDADI
}

\author{
Vicky Ariandi, Febri Hadi , Defra Irawan \\ Universitas Putra Indonesia YPTK Padang \\ E-mail: vicky_tanjung@yahoo.com¹,febri_hadi@upiyptk.ac.id², defrairawan.di@gmail.com ${ }^{3}$
}

\begin{abstract}
Abstrak
Telah dilakukan penelitian pada Kharisma Motor, dimana permasalahan yang dijadikan dasar dalam penulisan ini yaitu sistem pendukung keputusan dalam penentuan suku cadang yang laris dengan metoda topsis dan bordadi. Melalui proses observasi langsung kelapangan telah didapat kelemahan-kelemahan sistem yang ada. Walaupun tidak secara keseluruhan namun lebih mengarah pada masalah yang spesifik, namun diharapkan dapat memberikan kontribusi yang berarti kepada pengguna sistem. Penulis merancang sistem pendukung keputusan dalam penentuan suku cadang yang laris dengan metoda topsis dan bordadi yang mampu menanggulangi masalah-masalah pada Kharisma Motor dan dapat menghasilkan informasi tepat pada waktunya serta hasil dari informasi tersebut bisa lebih akurat. Dalam merancang sistem baru ini digunakan bahasa pemrograman PHP, UML dan database MySQL, Dengan adanya metoda topsis dan bordadi pada Kharisma Motor dapat meningkatkan mutu dan kualiatas sekolah serta data laporannya yang jelas dan berkala serta membantu mempercepat proses penentuan suku cadang yang laris semula secara manual menjadi terkomputerisasi dan tersimpan dalam system database, sehingga penyajiaan informasi data Kharisma Motor lebih cepat, akurat dan mudah.
\end{abstract}

Kata kunci: Informasi, Metoda, MySQL, PHP, Sistem, Topsis Dan Bordadi

\section{Pendahuluan}

\subsection{Latar Belakang Masalah}

Kemajuan Ilmu Pengetahuan dan Teknologi (IPTEK) yang sangat pesat ini, telah menjadikan kebutuhan informasi menjadi salah satu ciri utama yang sangat penting pada era globalisasi saat ini. Hal ini telah membawa pengaruh yang sangat besar di berbagai bidang baik untuk masa sekarang maupun masa yang akan datang. Khususnya dalam bidang komputer yang telah mengalami kemajuan yang sangat cepat disebabkan tuntutan terhadap informasi yang dihasilkan. Oleh karena itu, hal ini bukan lagi merupakan sesuatu yang baru bagi kita, sehingga sepatutnyalah kita menyadari arti pentingnya komputer dalam bidang pengolahan data dan pendukung keputusan di perusahaan, sekolah atau instansi dan badan organisasi lainnya, sehingga muncul istilah yang dikenal dengan Sistem pendukung keputusan (SPK).

Sistem pendukung keputusan (SPK) merupakan sekumpulan elemen yang saling berhubungan untuk membentuk suatu kesatuan dalam proses pemilihan berbagai alternative tindakan guna menyelesaikan suatu masalah, sehingga masalah tersebut dapat diselesaikan secara efektif dan efisien. Sistem pendukung keputusan dibangun untuk mendukung solusi atas suatu masalah atau untuk mengevaluasi suatu peluang.Sistem pendukung keputusan seperti itu disebut aplikasi sistem pendukung keputusan.

Sistem pendukung keputusan telah diterapkan pada penelitian yang di tulis oleh Standy (2012).Sistem pendukung keputusan tersebut merupakan Sistem pendukung keputusan untuk pemilihan rumah tangga miskin yang berhak menerima bantuan beras miskin dengan menggunakan basis data fuzzy.Sistem yang dibangun memiliki kemampuan untuk menyelesaikan data-data yang bersifat ambiguous.Dimana untuk menyelesaikan data-data yang bersifat ambiguous tersebut, dibutuhkan kemampuan penanganan query yang memiliki variabel-variabel linguistic

Dalam penelitian ini difokuskan pada sistem pendukung keputusan (SPK) dengan menerapkan metode Topsis dan Borda. Metode Topsis dan Borda merupakan salah satu metode pengambilan keputusan yang dapat digunakan dalam mendukung keputusan menentukan suku cadang yang laris, dimana proses 
pengambilan keputusan berdasarkan pada konsep out ranking dengan menggunakan perbandingan berpasangan dari alternatif-alternatif atau suku cadang berdasarkan kriteria-kriteria yang ditetapkan. Metode Topsis dan Borda digunakan pada kondisi dimana alternatif yang kurang sesuai dengan kriteria dieliminasi, dan alternatif yang sesuai dapat dihasilkan.Dengan demikian Metode Topsis dan Borda sangat mungkin digunakan untuk mendukung keputusan dalam menentukan suku cadang yang laris pada Kharisma Motor.

Kharisma Motor merupakan sebuah perusahaan yang bergerak dibidang penjualan suku cadang motor. Permasalahan yang sedang dihadapi oleh Kharisma Motor adalah kesulitan dalam menentukan suku cadang yang laris dan tidak laris serta berpengaruh kepada keputusan dalam pembelian suku cadang sehingga stock sering menumpuk di gudang atau sering juga tidak ada digudang (stock habis). Hal tersebut sangat berdampak buruk bagi Kharisma Motor dalam menjalankan kegiatan operasinya.Untuk mengatasi hal tersebut sudah saatnya diterapkan Sistem pendukung keputusan (SPK) untuk mendukung keputusan dalam penentuan suku cadang yang laris.

Berdasarkan permasalahan di atas penulis tertarik untuk merancang sebuah sistem pendukung keputusan yang tujuannya dapat membantu dan mempermudah pemilik Kharisma Motor dalam menentukan jenis suku cadang yang laris untuk membantu dalam menentukan rencana pembelian suku cadang untuk bulan berikutnya, demi kemajuan Kharisma Motor tersebut yang dituangkan dalam bentuk skripsi dengan judul "SISTEM PENDUKUNG KEPUTUSAN DALAM PENENTUAN SUKU CADANG YANG LARIS PADA KHARISMA MOTOR DENGAN METODA TOPSIS DAN BORDADI"

\subsection{Perumusan Masalah}

Berdasarkan latar belakang yang telah diuraikan di atas maka dapat disimpulkan rumusan masalah pada penelitian yaitu:

1. Bagaimana merancang dan membangun sistem pendukung keputusan menentukan suku cadang yang laris dengan metode Topsis dan Bordadi pada Kharisma Motor?

2. Bagaimana penggunaan bahasa pemrograman PHP bisa lebih efisien membantu dalam sistem pendukung keputusan menentukan suku cadang yang laris?

Bagaimana implementasi sistem pendukung keputusan dalam penentuan menentukan suku cadang yang laris bisa tepat sasaran?

\subsection{Hipotesis}

Dengan mengoptimalkan penggunaan ilmu pengetahuan dan teknologi khususnya komputer dalam sistem pendukung keputusan menentukan suku cadang yang laris, maka penulis dapat mengemukakan suatu hipotesa sebagai berikut :

1. Denganadanyasistempendukungkeputusan dengan menggunakan metode Topsis dan Bordadi diharapkan dapatmembantupara pengambilkeputusandalammenentukan suku cadang yang laris.

2. Denganmenerapkanbahasapemrograman PHPpadasistempendukungkeputusanakandenganmudah, cepatdanlebihefisiendalammenentukankeputusan.

3. Denganmenggunakansistempendukungkeputusanini proses yang dilakukanuntukmenentukan suku cadang yang laris bisatepatsasaran.

\subsection{Ruang Lingkup Penelitian}

Agar penelitian terhadap sistem lebih terarah dan tepat sasaran, maka penulis memberikan batasan terhadap permasalahan antara lain :

1. Sistem pendukung keputusan menentukan suku cadang yang laris.

2. Pengolahan data dilakukan dengan menggunakan metode Topsis dan Bordadi.

3. Penentuan kriteria yang dipakai dalam menentukan suku cadang yang laris ini dibatasi hanya lima kriteria saja.

\subsection{Tujuan dan Manfaat Penelitian}


Berdasarkan identifikasi masalah maka tujuan dari penelitian ini adalah sebagai berikut :

1. Mendesain suatu sistem yang untuk menentukan suku cadang yang laris.

2. Untuk menerapkan betapa pentingnya peranan komputer dalam penyimpanan data dan memproses data sehingga menentukan suku cadang yang laris tepat sasaran.

3. Untuk mengembangkan sistem informasi yang dari penyimpanan berupa arsip, menjadi penyimpanan ke dalam program aplikasi yang menggunakan bahasa pemrograman PHP.

memperoleh suatu manfaat yaitu sebagai berikut :

Berdasarkan rumusan masalah dan tujuan yang telah dipaparkan sebelumnya, diharapkan memperoleh suatu manfaat yaitu sebagai berikut :

1. Bagi Penulis

penelitian ini merupakan sarana pengembangan pengetahuan Dengan adanya penelitian penulis dapat merancang sebuah sistem pendukung keputusan menentukan suku cadang yang laris dengan metode Topsis dan Bordadi.

2. Bagi Kharisma Motor

Dengan adanya sistem pendukung keputusan ini dapat membantu dalam menentukan suku cadang yang laris.

3. Bagi Masyarakat

Penelitian ini merupakan sarana pembelajaran bagi masyarakat, dengan adanya penelitian ini masyarakat dapat memahani sistem pendukung keputusan menentukan suku cadang yang laris dengan metode Topsis dan Bordadi

\section{Tinjauan Literatur}

\subsection{Pengertian Sistem}

Sistem didefinisikan sebagai sekumpulann prosedur yang saling berkaitan dan saling berhubungan untuk melakukan suatu tugas secara bersama-sama (I Putu Agus Eka Pratama, 2014)

Sistem adalah sekelompok elemen-elemen yang terintegrasi dengan tujuan yang sama untuk mencapai suatu tujuan. Terdiri dari sejumlah sumber daya manusia, material, mesin, uang dan informasi. Sumber daya tersebut bekerja sama menuju tercapainya suatu tujuan tertentu yang ditentukan oleh pemilik atau manajemen. (Yakub, 2012).

Sistem adalah kumpulan atau himpunan dari unsur atau variabel-variabel yang saling terkait, saling berinteraksi, dan saling tergantung satu sama lain untuk mencapai tujuan (Hamim Tohari, 2013). Oleh sebab itu dalam membangun suatu sistem, kita harus paham betul konsep dasar sistem itu sendiri.Sebagaiman gambaran, jika sebuah sistem terdapat elemen yang tidak memberikan manfaat dalam mencapai tujuan bersama, maka elemen tersebut dapat dipastikan bukanlah bagian dari sistem.

\subsection{Elemen Sistem}

Ada beberapa elemen-elemen yang saling terkait dalam membentuk sebuah sistem, (Abdul Kadir, 2013) yaitu:

1. Tujuan

Setiap sistem memiliki tujuan ( $g$ oal), entah hanya satu atau banyak. Tujuan inilah yang akan menjadi motivasi yang mengarahkan sistem. Tanpa tujuan, sistem menjadi tak terarah dan tak terkendali. Tentu saja tujuan antara satu sistem dengan sistem lain berbeda-beda. Begitu pula yang berlaku pada sistem informasi.Setiap sistem informasi memiliki tujuan, tetapi dengan tujuan yang berbeda-beda. Walaupun begitu, tujuan utama yang umum ada tiga macam yaitu:

a. Untuk mendukung fungsi kepengurusan manajemen

b. Untuk mendukung pengambilan keputusan manajemen

c. Untuk mendukung kegiatan operasi perusahaan.

2. Masukan 
Masukan (Input) sistem adalah segala sesuatu yang masuk yang masuk ke dalam sistem yang selanjutnya menjadi bahan untuk diproses. Masukan dapat berupa hal-hal berwujud (tampak secara fisik) maupun yang tidak tampak.Contoh masukann yang berwujud adalah bahan mentah, sedangkan contoh yang tidak berwujud adalah informasi (misalnya permintaan jasa dari pelanggan). Pada sistem informasi masukan dapat berupa data transaksi dan data non transaksi (misalnya surat pemberitahuan) serta intruksi.

3. Proses

Proses merupakan bagian yang melakukan perubahan atau transformasi dari masukan menjadi keluaran yang berguna, misalnya informasi dan produk tetapi juga bisa hal-hal yang tidak berguna, misalnya sisa pembuangan atau limbah. Pada pabrik kimia proses dapat berupa pemanasan bahan mentah. Pada rumah sakit, proses dapat berupa aktivitas pembedahan pasien.Pada sistem informasi, proses dapat berupa suatu tindakan yang bermacam. Meringkas data, melakukan perhitungan dan mengurutkan data merupakan beberapa contoh proses.

4. Keluaran

Keluaran (Output) merupakan hasil dari pemrosesan.Pada sistem informasi, keluaran bisa berupa suatu informasi, saran, cetakan laporan, dan sebagainya.

5. Mekanisme pengendalian, dan Umpan balik

Mekanisme pengendalian (Controll Mekanism) diwujudkan dengan menggunakan umpan balik (feedback), yang mencerminkan keluaran. Umpan balik ini digunakan untuk mengendalikan baik masukan maupun proses. Tujuannya adalah mengatur agar sistem berjalan sesuai dengan tujuan.Dalam bentuk yang sederhana, dilakukan pembandingan antara keluaran sistem dan keluaran yang dikehendaki (Standart).

Untuk lebih jelasnya mengenai elemen sistem dapat dilihat pada gambar dibawah ini:

Sumber : (Abdul Kadir, 2013)

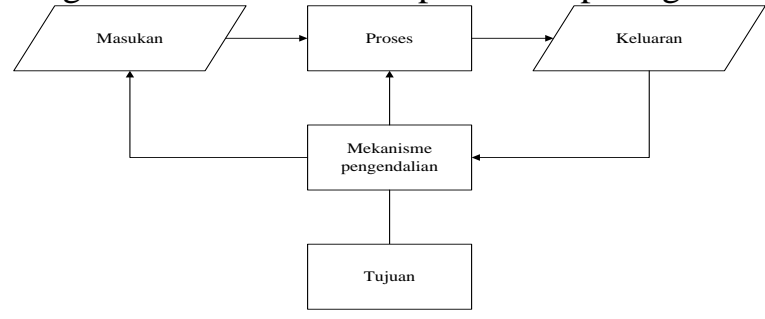

Gambar 1 Sistem dan Elemen-elemenya

\subsection{Pengertian Informasi}

Informasi di dalam sebuah perusahaan yang sangat penting untuk mendukung kelangsungan perkembangannya. Akibat bila kurang mendapatkan informasi, dalam waktu tertentu perusahaan akan mengalami ketidakmampuan mengontrol sumber daya, yang pada akhirnya akan mengalami kekalahan dalam bersaing dengan lingkungan pesaingnya.

Informasi merupakan hasil pengolahan data dari satu atau berbagai sumber, yang kemudian diolah, sehingga memberikan nilai, arti dan manfaat (I Putu Agus Eka Pratama, 2014)

Informasi (information) adalah data yang di olah menjadi bentuk lebih berguna dan lebih berarti bagi yang menerimanya atau data yang diprosessedemikian rupa sehingga meningkatkan pengetahuan seseorang yang menggunakan. Sistem apapun tanpa ada informasi tidak akan berguna, karena sistem tersebut akan mengalami kemacetan dan akhirnya berhenti. Informasi dapat berupa data mentah, data tersusun, kapasitas sebuah saluran informasi dan sebagainya.(Yakub, 2012).

Ada beberapa pengertian lain tentang informasi (Abdul Kadir, 2013), yaitu:

1. Menurut McFadden, dkk.

Informasi adalah data yang telah diproses sedemikian rupa sehingga meningkatkan kemampuan seseorang yang menggunakan data tersebut.

2. Menurut Shanon dan Weaver 
Inforamasi adalah jumlah ketidakpastian yang dikurangi ketika sebuah pesan diterima.

3. Menurut Davis.

Informasi adalah data yang telah diolah menjadi sebuah bentuk yang berarti bagi penerimanya dan bermanfaat dalam pengambilan keputusan saat ini atau masa yang akan datang.

Adapun proses transformasi data menjadi informasi dapat dilihat pada Gambar 2.2 berikut:

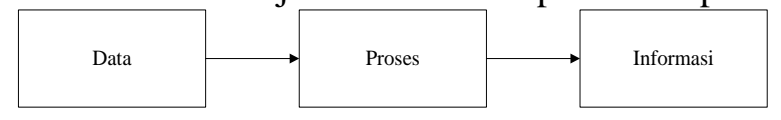

Sumber : (Abdul Kadir, 2013)

Gambar 2 Transformasi Data Menjadi Informasi

Untuk memperoleh informasi yang bermanfaat bagi penerimanya, perlu dijelaskan bagaimana siklus yang terjadi atau dibutuhkan dalam menghasilkan informasi. Pertaman-tama data dimasukan kedalam model yang umumnya memiliki urutan proses tertentu dan pasti, setelah diproses akan dihasilkan informasi tertentu yang bermanfaat bagi penerima sebagai dasar dalam membuat suatu keputusan atau melakukan tindakan tertentu.

Suatu Informasi dapat dikatakan benilai apabila telah memenuhi beberapa kriteria, yaitu akurat (acuracy), tepat waktu (timeliness), dan relevan (relevancce).

1. Akurat

Informasi yang dihasilkan harus bebas dari kesalahan-kesalahan. Akurat juga berarti informasi harus jelas mencerminkan maksudnya.

2. Tepat pada waktunya

Informasi tepat waktu, karena informasi merupakan landasan di dalam pengambilan keputusan di tingkat manajemen yang lebih tinggi.

3. Relevan

Informasi tersebut mempunyai manfaat untuk pemakainya, Relevansi informasi untuk setiap pemakai yang satu dengan yang lainnya berbeda.

\subsection{Pengertian Sistem Informasi}

Sistem informasi merupakan gabungan dari empat bagian utama. Bagian utama tersebut mencakup perangkat lunak (Software), perangkat keras (Hardware), Infrastruktur dan Sumber daya manusia (SDMM) yang terlatih. Keempat sistem utama ini saling berkaitan untuk menciptakan sebuah sistem yang dapat mengolah data menjadi informasi yang bermanfaat (I Putu Agus Eka Pratama, 2014)

Ada beberapa pengertian lain tentang sistem informasi (Abdul Kadir, 2013), yaitu:

1. Menurut Alter

Sistem Informasi adalah kombinasi antara prosedur kerja, informasi, orang dan teknologi informasi yang diorganisasikan untuk mencapai tujuan dalam sebuah organisasi.

2. Menurut Bodnar dan Hopwood.

Sistem Informasi adalah kumpulan perangkat keras dan perangkat lunak yang dirancang untuk mentransformasikan data kedalam bentuk informasi yang berguna.

3. Menurut Galinas, Oram, dan Weggins

Sistem Informasi adalah suatu sistem buatan manusia yang secara umum terdiri atas sekumpulan manual yang dibuat untuk menghimpun, menyimpan, dan mengelolah data serta menyediakan informasi keluaran kepada pemakai.

4. Menurut Hall.

Sistem Informasi adalah sebuah rangkaian prosedur formal di mana data dikelompokkan, diproses menjadi informasi, dan didistribusikan kepada pemakai. 
5. Menurut Tuban, McLean, dan Wetherbe

Sebuah sistem informasi mengumpulkan, memproses, menyimpan, menganalisis, dan menyebarkan informasi untuk tujuan yang spesifik.

6. Menurut Wilkinson

Sistem informasi adalah kerangka kerja yang mengkoordinasikan sumber daya (manusia, komputer) untuk mengubah masukan (input) menjadi keluaran (informasi),guna mencapai sasaran-sasaran perusahaan.

\subsubsection{Komponen Sistem Informasi}

dalam suatu sistem informasi terdapat komponen-komponen (Abdul Kadir, 2013), seperti:

1. Perangkat keras (Hardware): Mencakup piranti-piranti fisik seperti komputer dan printer.

2. Perangkat Lunak (Software) atau program: Sekumpulan instruksi yang memungkinkan perangkat keras untuk dapat memproses data.

3. Prosedur: Sekumpulan aturan yang diapakai untuk menwujudkan pemrosesan data dan pembangkitan keluaran yang dikehendaki.

4. Orang: semua pihak yang bertanggung jawab dalam pengembangan sistem informasi, pemrosesan, dan penggunanaan keluaran istem informasi.

5. Basis data (Database): Sekumpulan tabel, hubungan, dan lain-lainya yang berkaitan dengan penyimpanan data.

6. Jaringan komputer dan komunikasi data: sistem penghubung yang memungkinkan sumber dipakai secara bersamaan atau dapat diakses oleh sejumlah pemakai sistem.

\subsubsection{Sistem Pendukung Keputusan}

SPK menggunakan sistem informasi yang berbasis komputer yang fleksibel, interaktif, dan dapat diadaptasi, yang dikembangkan untuk mendukung solusi untuk masalah manajemen spesifik yang tidak terstruktur. SPK menggunakan data, memberikan antarmuka pengguna yang mudah, dan dapat menggabungkan pemikiran pengambil keputusa.(Turban dkk, 2005).

\subsubsection{Metode Topsis Dan Borda}

TOPSIS (Technique For Orders Reference bySimilarity to Ideal Solution) merupakan salah satu metode pemecahan masalah pengambilan keputusan yang memiliki banyak kriteria atau atribut, dimana berdasarkan pada konsep dimana alternatif terpilih yang terbaik tidak hanya memilki jarak terpendek dari solusi ideal positif, melainkan juga harus memilki jarak terpanjang dari solusi ideal negative (Cheng, 2000). TOPSIS banyak digunakan dikarenakan memiliki konsep sederhana dan mudah dipahami, komputasinya efisien dan memiliki kemampuan untuk mengukur kinerja relatif dari alternatif-alternatif keputusan dalam bentuk matematis yang sederhana.

\section{Metodologi}

Agar dalam penulisan laporan ini terfokus dan tidak terlepas dari data dan informasi yang Agar dalam penulisan skripsi ini terfokus dan tidak terlepas dari data dan informasi yang berhubungan dengan pokok pembahasan maka penulis menggunakan beberapa metode penelitian untuk mendapatkan data-data tersebut.

1. Penelitan Lapangan(Field Research) Penelitian langsung ke Kharisma Motor untuk mengumpulkan data serta wawancara dengan salah seorang karyawan Kharisma Motor.

2. Penelitian Kepustakaan (Library Reseach)

Penelitian dilakukan untuk mendapatkan data sekunder mengumpulkan data dengan cara membaca buku-buku atau literatur yang berhubungan dengan dengan masalah yang akan diteliti.

3. Penelitian Laboratorium (Laboratory Reseach)

Dalam hal ini digunakan hardware maupun software agar tujuan perancangan tercapai. 


\section{Analisa Dan Hasil}

Dari hasil penelitian yang telah dilakukan baik dengan melakukan survey langsung ke Kharisma Motor maupun tidak langsung, maka dapat diuraikan kerja sistem yang ada Kharisma Motor. Dimana dalam pengolahan data inventory,Kharisma Motor membutuhkan waktu yang lama dan kurang efisien karena masih belum optimalnya penggunaan komputerisasi dan analisa yang dilakukan secara manual.

\subsection{Use Case Diagram}

Adapun Usecase diagram dari sistem yang diancang dapat dilihat pada gambar dibawah gambar 4.1 .

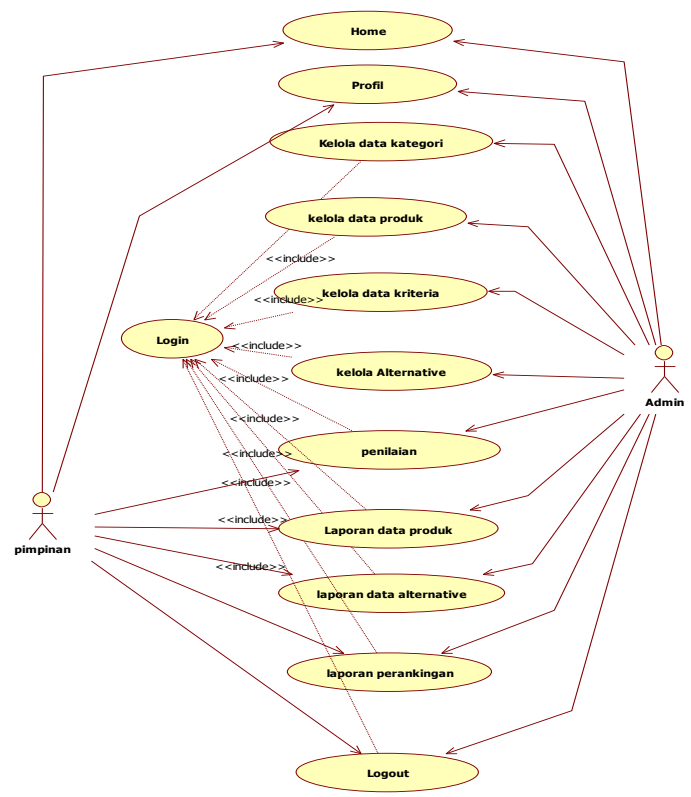

Gambar 4.1 Use Case Diagram

\subsection{Class Diagram}

Adapun class diagram dari sistem yang diarancang dapat dilihat pada gambar 4.2 berikut: 


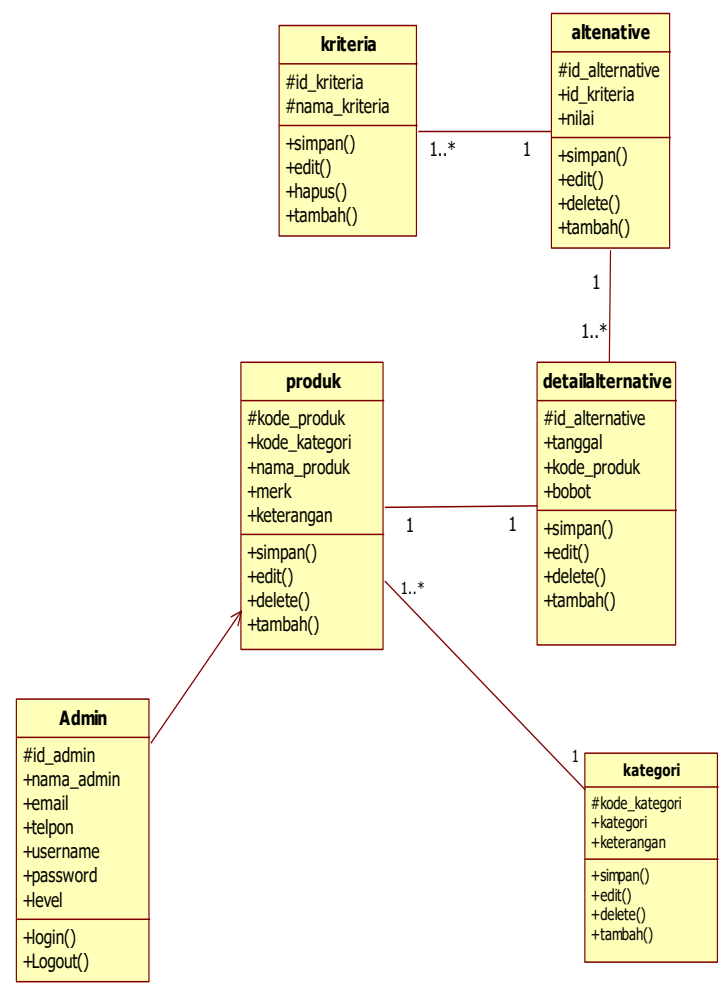

Gambar 4.2 Class Diagram

\subsection{Pengujian Program}

Pada bagian pengujian program ini akan dijelaskan mengenai penggunaan dari aplikasi yang dibuat. Penjelasan aplikasi yang dibuat meliputi tampilan aplikasi, fungsi kontrol dalam aplikasi, serta cara penggunaanya. Pada sub bab akan dijelaskan tentang penggunaan aplikasi per sistem menu, mulai dari tampilan menu utama, fungsi dan cara penggunaannya sampai selesai.

\section{Tampilan Form Login}

Disini terlihat form login yang digunakan untuk keamanan sistem, untuk dapat masuk ke sistem pendukung keputusan dalam penentuan suku cadang yang laris pada Kharisma Motor Padang kita harus mengentrikan username dan password. seperti Gambar 5.15.



Gambar 5.15. Form Login

\section{Tampilan Menu Utama}

Disini terlihat beberapa menu pada Menu utama yaitu menu Entry Produk, Kategori, Kriteria, Alternative dan Laporanseperti Gambar 5.16. 




Gambar 5.16. Menu Utama

\section{Entry Kriteria}

Form Ini berguna untuk mendata seluruh kriteria. Terdapat tombol Simpan/Ubah, berguna dalam menyimpan data ke database dan memperbaharui data dalam database, serta tombol keluar untuk keluar.Untuk menginputkan data kriteria klik entri criteria pada menu, dan isi data kriteria seperti Gambar 5.17 .



Gambar 5.17. Entry Data Kriteria

\section{Entry Kategori}

Halaman entri data Kategori merupakan halaman yang digunakan oleh admin untuk mengentrikan data Kategori ke dalam database.Pada halaman entri data Kategori terdapat field-field yang harus diisi oleh admin.Adapun tampilan halaman entri data Kategori dapat dilhat pada Gambar 5.18.

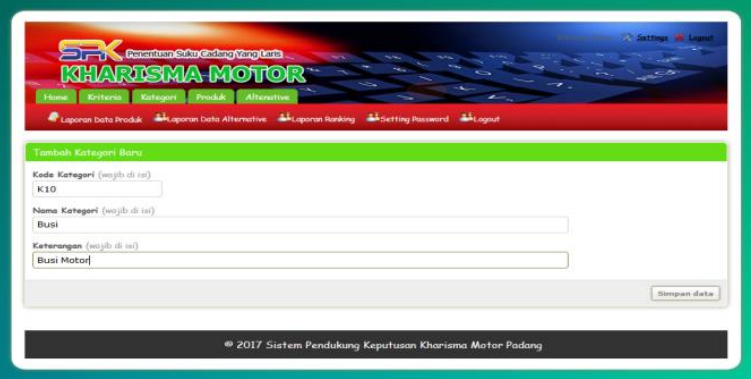

Gambar 5.18. Entry Data Kategori

\section{Entry Produk}

Halaman entri data Produk merupakan halaman yang digunakan oleh admin untuk mengentrikan data Produk ke dalam database.Pada halaman entri data Produk terdapat field-field yang harus diisi oleh admin.Adapun tampilan halaman entri data Produk dapat dilhat pada Gambar 5.19. 


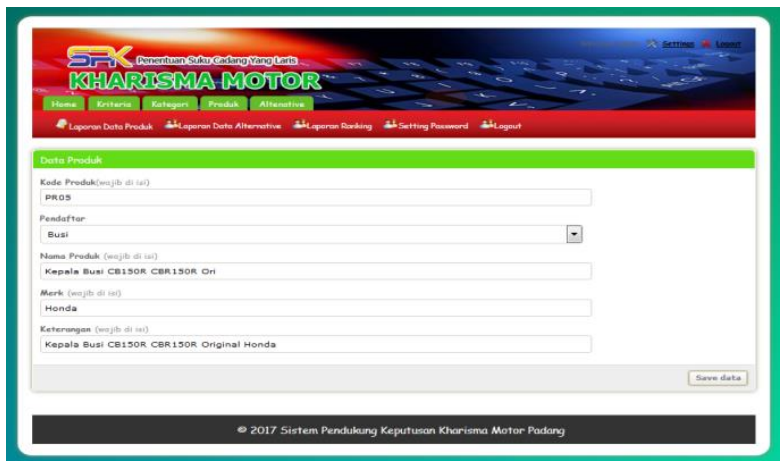

Gambar 5.19. Entry Data Produk

\section{Entry Alternative}

Halaman entri data Alternative merupakan halaman yang digunakan oleh admin untuk mengentrikan data Alternative ke dalam database.Pada halaman entri data Alternative terdapat field-field yang harus diisi oleh admin.Adapun tampilan halaman entri data Alternative dapat dilhat pada Gambar 5.20.

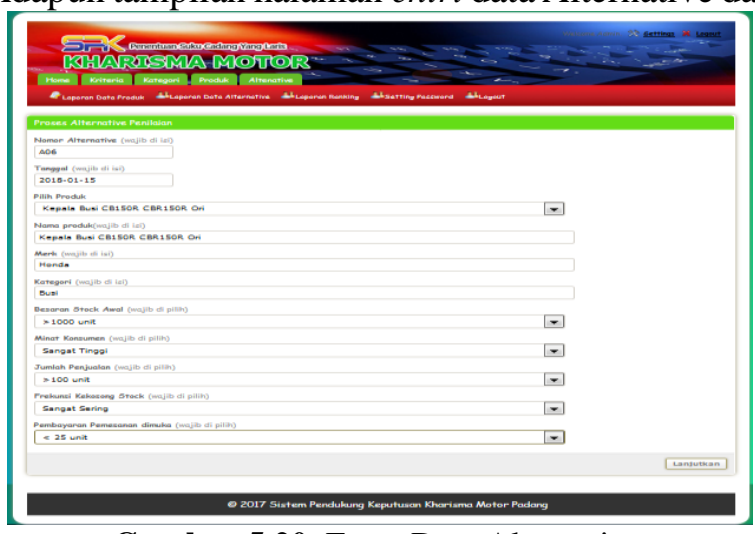

Gambar 5.20. Entry Data Alternative

\section{Laporan Data Produk}

Laporan Data Produk merupakan laporan yang memuat data-data produk yang terdapat pada Kharisma Motor Padang. Sebelum laporan dimunculkan akan tampil form penghubung laporan berfungsi sebagai pemanggil laporan data Laporan Data Produk. Dengan memasukan nama nama dan tanggal pada form tersebut maka laporan data produk akan muncul. Untuk lebih jelasnya dapat dilihat pada Gambar 5.21 .



\section{Laporan Alternative}

Laporan Alternative merupakan laporan yang memuat alternative penilaian data-data produk yang terdapat pada Kharisma Motor Padang. Sebelum laporan dimunculkan akan tampil form penghubung 
laporan berfungsi sebagai pemanggil laporan data Laporan Data Alternative Penialaian Produk. Dengan memasukan nama nama dan tanggal pada form tersebut maka laporan data alternative penilaian produk akan muncul. Untuk lebih jelasnya dapat dilihat pada Gambar 5.22.

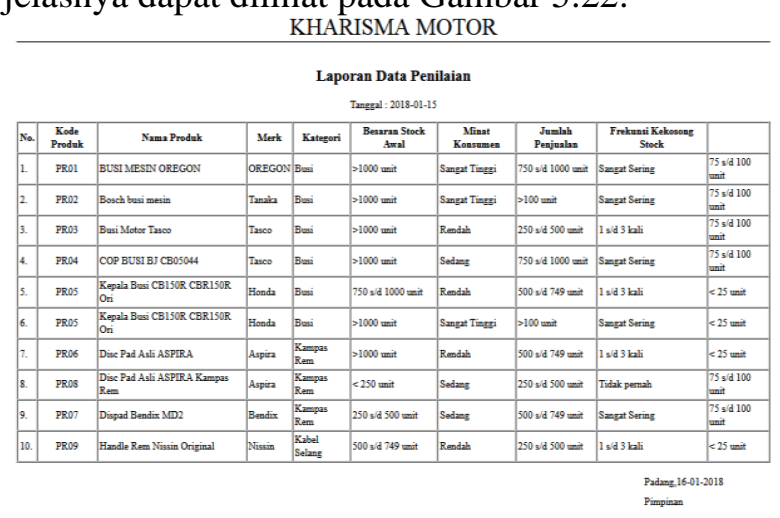

Gambar 5.22. Laporan Alternative

\section{Laporan Rangking}

Laporan Data Rangkin merupakan laporan yang memuat data-data nilai produk yang terdapat pada Kharisma Motor Padang. Sebelum laporan dimunculkan akan tampil form penghubung laporan berfungsi sebagai pemanggil laporan data Laporan Data Produk. Dengan memasukan nama nama dan tanggal pada form tersebut maka laporan data rangking penilaian produk akan muncul. Untuk lebih jelasnya dapat dilihat pada Gambar 5.23.

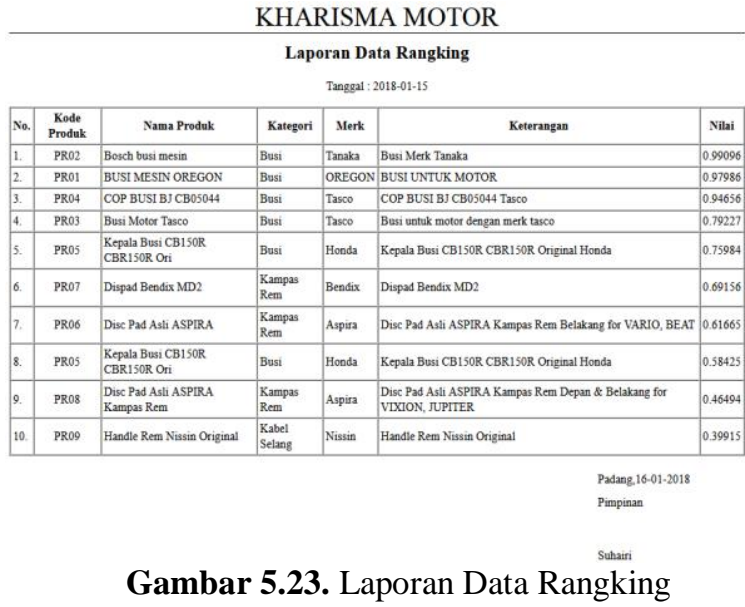

\subsection{Kesimpulan}

Berdasarkan atas penelitian yang telah penulis lakukan pada Kharisma Motor Padang, maka dapat diambil kesimpulan sebagai berikut :

1. Sistempendukungkeputusan dengan menggunakan metode Topsis dan Bordadidapatmembantupara pengambilkeputusandalammenentukan suku cadang yang laris pada Kharisma Motor.

4. Denganmenerapkanbahasapemrograman PHPdan didukung dengan database MySQL padaperancangan sistempendukungkeputusanmaka akandenganmudah, cepatdanlebihefisiendalammenentukankeputusan.

5. Denganmenggunakansistempendukungkeputusandapat memudahkan Kharisma Motor dalam menentukan suku cadang yang laris dan lebihtepatsasaran.

\subsection{Saran-saran}


Pada akhir penulisan ini, penulis mencoba memberikan saran-saran kepada Kharisma Motor. Adapun saransaran yang dapat penulis berikan adalah sebagai berikut:

1. Peralihan sistem yang ada tidak dilakukan secara mendadak, tetapi terlebih dahulu dilakukan penyesuaian antara sistem yang ada selama ini dengan sistem yang baru.

2. Diadakan pelatihan bagi tenaga kerja yang akan mengoperasikan sistem baru atau merekrut tenaga kerja baru yang professional di bidang komputer.

3. Penempatan Perangkat keras harus dijauhkan dari sumber api dan tempat yang lembab karena akan mengakibatkan kerusakan fisik pada perangkat keras.

\section{DAFTAR PUSTAKA}

[1] A.S, Rosa, Shalahuddin, M. 2013.Rekayasa Perangkat Lunak. Bandung: Informatika bandung.

[2]Hasanah, Uswatun. 2013. SISTEM INFORMASI PENJUALAN ON_LINE PADA TOKO KREATIF SUNCOM PACITAN. Jurnal Emba

[3]Kadir, Abdul. 2013. Pengenalan Sistem Informasi. Yogyakarta :Andi

[4]Machmud, Rizal. 2013. Peranan Penerapan Sistem Informasi Manajemen TerhadapEfektivitas Kerja Pagawai Lembaga PemasyarakatanNarkotika (lapastika) Bollangi Kabupaten Gowa. Vol.9 No.3. Jurnal Emba

[5]Nugrahanti, Fatim (2015). Perancangan Sistem Informasi Inventory Sparepart mesinfotocopy dengan menggunakan visual delphi 7(Studi Kasus di UD. Eka Taruna Madiun). Vol.2 No.2 Jurnal Emba.

[6]Oei, Standy. 2012. Sistem pendukung keputusan untuk penentuan penerima beras miskin menggunakan basis data fuzzy. Jurnal Emba.

[7]Pratama, I Putu Agus Eka, 2014.Sistem Informasi dan Implementasinya.Bandung :Informatika Bandung

[8]Raharjo, Budi. 2011. Belajar Otodidak Membuat Database Menggunakan MySQL.Bandung : Informatika Bandung

[9]Saputra, Ade. 2015. Rancang bangun sistem pendukung keputusan penentuan keluarga miskin. Jurnal Emba

[10]Sari, Renny Puspita. 2014. PERANCANGAN SISTEM PENDUKUNG KEPUTUSAN KELOMPOK METODE TOPSIS DAN BORDA UNTUK EVALUASI KEGIATAN PENANGANANINFRASTRUKTUR JALAN. Jurnal Emba

[11]Suryeni, Eni. 2015. Sistem Pendukung Keputusan Kelayakan Penerimaan Bantuan Beras Miskin Dengan Metode Weighted Product DiKelurahan Karikil Kecamatan Mangkubumi KotaTasikmalaya. Jurnal Emba

[12]Tata Sutabri. 2012. Analisis Sistem Informasi. Yogyakarta: Andi

[13]Tohari, Hamim. 2013. Analisis Serta Perancangan Sistem Informasi Melalui Pendekatan UML. Yogyakarta : Andi

[14]Yakub. 2012. Pengantar Sistem Informasi, Yogyakarta: Graha Ilmu 